\title{
Hair and Female Identity
}

\section{Reading Women's Hair in The Mass Media}

\author{
Sitti Murniati Muhtar ${ }^{1 \text { a }}$; Muh Iqbal Sultan ${ }^{1}$; Andi Subhan Amir ${ }^{1}$; Sitti Nurfajriani Syam² \\ ${ }^{1}$ Department of Communication, Hasanuddin University, Makassar, Indonesia \\ ${ }^{2}$ Department of Accounting, Hasanuddin University, Makassar, Indonesia \\ ${ }^{a}$ Corresponding author: sittimurniatimuhtar78@gmail.com
}

\begin{abstract}
This article discusses the importance of women hair as an identity symbol in relation with the development of information technology and industry. Women hair has became a commodificated human organ. Advertisements of some hair cosmetic products that showed beautiful image of celebrities' hair have bother women as media consumers. Media has been continuing to reproduce taht image. This because an identity crisis among women that could send them into a condition called mimetic crisis. Women try hard to "become-a-like" the image that shown in media, especially though advertisements there. Then, the meaning of beautiful is constructed by those adversitiments rather yhat by women. Therefore, women face two options : freedom to express themselves in their own style, or drift into media and indutry explanations.
\end{abstract} crisis

Keywords—industry, media, consumption, identity, mimetic

\section{INTRODUCTION}

Hair is one of the attributes of the body that most sucked human attention, in addition to skin, face and body self. Hair becomes a topic that is often discussed in various articles published in mass media, ranging from magazines, newspapers, to the internet. Not only a small talk in party, about the hair is also going on radio, television, even the theme of the songs in Indonesia. Maybe we still remember the dangdut song sung by Evi Tamala and Doyok, whose lyrics discuss about hair, "Hair, who's have this hair, darling....[18]".

Not just about being discussed, discussed, or being a song material, hair is also one of the body attributes sold by the world beauty industry. The presence of dozens of advertisements of shampoo products, hair vitamins and hair dyes that every day greet us on television, magazines and newspapers, as well as large balihos on the highway, proof that hair is an object of interest to the industry to accumulate profits.

Currently, there are approximately seven major companies offering beauty products for hair in magazines, radio and television: Lionwings, Unilever, P\&G, Mandom, Lee sara, Makarizo and Kinocare, with a variety of trademarks (brand). We can also access their products on the internet.

Through their respective websites or online shops, such as RatuKosmetik.com. not just a very limited ad duration or page, there are some companies that make special impressions on television or out door events to produce their products [15]. PT. Procter \& Gamble (P \& G), for example, created an advertisement star selection event for Pantene products and rejoice that aired on several private television stations in Indonesia. Out door events are also deliberately organized by Unilever under the Clear brand, PT Lionwings under the Zinc brand, and Mandom under the Gatsby brand [13].

In general, each company has more than one trademark, L'Oreal for example, has a brand Kerastase and Elseve. P\&G menguassai four trademarks, namely; Pantene, Rejoice, Head \& Shoulders and Herbal Essences. Unilever has Clear, Sunsilk, Lifebouy Shampoo and Dove Shampoo brands. Lionwings with emeron, Zinc, Page One Botanical Shampoo and Komodo (for children) [17]. Meanwhile, Mandom holds a trademark also has a variety of products for hair, ranging from shampoo, mask, spray, hinngga cream for hair styling [14]. These products can be categorized into: hair treatment, hair styling / hair dressing and hair color.

Industry attention to hair is also supported by the increasingly widespread salons and beauty clinics in major cities in Indonesia. Makarizo Hair Studio, Metahair Center, Salon Rudi Hadisuwarno, Million Cut of Maritim, May May Salon, Hairworls and Alfons salons are some of the reputed salons that offer care and hairdressing. Salon serves hair styling with a variety of styles, creambath, hair spa, rebonding is equipped with a makeup that suits the hairstyle.

Hair symbolism becomes very complex because it opens up a choice for everyone to show identity through diverse styles of hair. however, according to [7] in his theory of contradiction, there are three proportions that can be used to understand the current symbolic practice of hair. one of which is that the opposite sex has the opposite hair norm.

The proportion is based on two reasons, namely first, that although hair grows throughout the body only to the three areas that have the social meaning of head hair (on the scalp) facial hair (beard, mustache, eyebrows, eyelashes, hair in sight) and and hair growing (hair legs, hands, etc). second, hair can be modified in four principal ways. hair length, hair color, hairstyle and hair quantity can be varied, adjusted for gender, age, occupation, or personality. 
For women, head hair (hereinafter called "hair" only) is a crown that must always be maintained its beauty. various ways they will do to get beautiful hair because this section is a very important identity marker. like a phrase published in the 18th edition of September 1983 from a woman who had hair loss after radiation treatment for kakers, that "when you lose your hair, you will feel like you do not want to live again." for her hair has a very important meaning. The expression is the same as Hemingway's opinion that a girl is not a girl without her hair. this opinion shows that the hair becomes an inseparable part of the female figure.

Unlike women who identify themselves with head hair, for more-men, facial hair and body hair is more important than the head. facial hair and body hair become a symbol of masculinity. even so, some men are also worried about the signs of baldness on the hair.

Related to the hair model, in accordance with conventional norms in the community, there is a significant difference between women and men. In general, men have shorter hair than women. will be deemed to be deviating from the prevailing norm if there is a short-haired woman or a haired man. for women, long hair is a symbol of honor and a symbol of femininity. long hair is also a symbol of wealth because taking care of long hair requires a lot of money and tend to require a longer time compared with short hair care.

Women give more attention to the head hair by adding accessories, such as flowers, ribbons, headbands, hair clips, wigs, hoods or hats to make it look more attractive. women's hair styles also often change following the trend. once when they curl their hair and then straighten it, or vice versa, straighten hair and curl it again. women are more daring to experiment with hair color than men.

Meanwhile, male hairstyles tend to be similar or even similar to other men. in general they are also consistent with one hairstyle and not easy to change it. Men do not use many accessories to beautify their hair, except wear a hat to protect their heads from the sun and wigs to hide baldness. associated with hair color, men dye their hair to cover their white hair (gray hair) with a color that is almost the same as the previous hair color (dark color) [11].

Differences in views between women and men about hair is what drives the industry to make verified care products and hairstyling. each trademark (brand) offers different products for each sex. Unilever for example, under the Clear brand, this company creates a special shampoo product for men, the Clear Men. however, beauty products for hair are still dominated by products intended for women. therefore, it is only natural that the advertising of nursing and hair products involves many women, especially from celebrities, since their biggest consumers are (also) women.

\section{ANALYSIS AND DISCUSSION}

Advertising is a major promotional tool used by almost all companies around the world, including Indonesia. Advertising becomes an important communication tool between producers, distributors and consumers. this is in line with a statement posted on the general daily website of the afternoon, the ray of hope in 2002, that for consumer products such as shampoo, bath soap, toothpaste, there seems to be no strategic way to seize consumers, except by promoting or advertise.

The importance of promoting through the media is felt by PT. Gondo Wangi Sariaji, a company that produces and distributes Natur shampoo products. "I think the influence of advertising on sales is quite large because through the ilan that aired in print and electronic media will explain the benefits of products we offer to consumers," said Andi hariadi, Marketing Director of PT. Gondo Wangisariaji. before his company promotes effectively, the name of the sampo product is Gondo Wangi [10]. however, this name is perceived as less commodial. "to be popular and easy to remember, we are looking for a new name eventually Natur name, even so, to change the name to be known known to consumers especially who have become loyal customers, need promotion, need to advertise," continued Andi. after the name of shampoo digandi with Natur, he also uses advertising media to communicate to consumers. the result, according to Andi quite effective. Natur Shampoo became one of the most purchased shampoo product [16]

Since the beginning of the 20th century, advertising has become a basic need for every company to offer its product sales. in europe and Ameriak, advertising becomes the answer to the changing mode of production (mode of production) and industrial management. At that time, industrial corporations developed into giant corporations by applying mechanical systems for mass production. there is not a single source of human life apart from the process of industrialization. society is attacked by thousands or even millions of products. This phenomenon, then encourage each company to expand the market to abroad. To provide information about its products, each company uses advertising as a communication tool [3]. In subsequent developments, advertising also contributes to his life (mode of Consumption) with a wide range of lifestyle has to offer. how does a woman's hair in advertisement? as large articles about women in the mass media revealed that long, black and luruss hair is part of the social constancy of female beauty that is preserved and reproduced by the media. this is as explained by Herri Permana in his article entitled "Pengaruh Iklan dalam Pencitraan dan Idealisasi Tubuh Perempuan" (My blog Journey) or Easter Lianawati's writing with Title Perempuan Tubuh dan kecantikan (A Feminist's Blog). Almost all shampoo and conditioner ads that aired on television or published in magazines also reinforce that opinion. Starting from Sunsilk Urang-Aring (Maria Renata), Sunsilk Black Shine (Krisdayanti), Zinc (Rossa), Emeron (Marshanda), Clear, Rejoice, Head \& Shoulders, to Pantine (Siti Nurhaliza, Annisa Pohan, Anggun), offers long, black and straight hair as a hairstyle that must be owned by Indonesian women [18]. One of Makarizo's advertisements in the June 2007 edition of Cosmopolitan magazine (p.137) also supports this view by presenting the results of a survey conducted in five major cities in Indonesia (Jakarta, Medan, 
Surabaya, Bandung and Makassar). That $83 \%$ of Indonesian women choose straight hair as the most popular hairstyles.

However, it seems that the social construction of hair in Indonesia is beginning to change as more information is abundant in the mass media. The rise of imported programs aired on television stations as well as the emergence of mini cinemas in shopping centers that play foreign films, changing people's perceptions of fashion and beauty, especially the concept of beautiful hair. Various types, colors and hairstyles from different countries invade the media consumer's space of thinking and offer aesthetic experience for the audience [12]. This is supported by the existence of an industry that produces a wide range of hair care and grooming products, which are widespread in domestic markets.

Currently, beautiful hair is no longer identical with straight hair. The appearance of these women curls or curls in shampoo ads is evidence of the statement. L'Oreal, for example, in the Kerastase brand advertisement with Oleo Curl product, in Cosmopolitan October 2007 edition [9] (p. 6-7), deliberately presents a model of curly hair. In Cosmopolitan June 2007 edition (p. 139), the same is done by Makarizo who promotes the product range of Exo Unique Wave System with Curly So Sexy jargon. In addition, Wella also gives special attention to curly hair by offering Wella High Hair Touch \& Feel. Similarly premises Dove or Sunsilk that no longer taboo presents women curls as a star ad.

Associated with hair color, Indonesian women as if already getting bored with black hair. This phenomenon can be seen from the increasing number of Indonesian celebrities who paint their hair with bright colors, such as: golden (blonde), brown, red, yellow, green, blue, purple, and other colors. Maia Estianty, Pingkan Mambo, Melly Goelow, Mulan Jameela and Inul Daratista are some Indonesian celebrities who often change hair color. Hair coloring products, for example: Ellipse, L'Oreal Professional Hair Color, Elseve, Makarizo Concept and Sunsilk Color Shine System, began to enliven the world of advertising homeland. Women with colorful hair were present in various advertisements in the mass media [5].

Meanwhile, Indonesian women who maintain long hair is also reduced. Dense demands of activity are made one by some to trim their hair to be shorter, other than the costly reason for long hair care. Asymmetrical haircuts (harajuku) even evolved into the most popular hairstyles today, which women and men favor.

\section{Consumption and Identity Crisis}

"He doesn't love me anymore"

“You don't love your own self. Try to see lusterless

$$
\begin{gathered}
\text { hair like this", } \\
\text { "oh yes, what my creased face!" }
\end{gathered}
$$

The dialogue quote was taken from one of Sunsilk Urang Aring's ads with Maria Renata as her model. Narrated in the ad, Maria Renata with disheveled hair complained about the attitude of her boyfriend who had no love for her anymore. Her friend, a woman with well-groomed hair, said it was natural that the girlfriend did not care anymore because Maria Renata's hair looked dull. Maria then uses Sunsilk Urang Aring. The next scene is the arrival of Mary's girlfriend to apologize who actually greeted Mary by throwing a cake to the face of his girlfriend.

This Sunsilk ad wants to explain to the audience, especially the women, about the importance of hair care. Because unkempt hair, in this context means dull hair, will make the owner unhappy. Therefore, according to the ad, we are required to have beautiful hair, which can only be obtained by using Sunsilk Urang Aring.

Consumption is an activity that cannot be separated from human existence on earth, which is a process of using or spending the value of an item as well as a process of production or construction, production or reconstruction of life at all levels, from things that are physical to something that is social [4]. In modern society, pleasure is the center of consumption activity. Pleasure is the attraction between the fantasy or imagination with the function and also the attraction of individual desire with social norms [1].

If consumption is an attempt to obtain satisfaction from the fulfillment of human needs, then advertisements that are shown in the mass media have no other function except to provide information to consumers about what goods / services they need to meet those needs, where to get it, how to use it, and what is the effect after taking it [4]. In general, advertising not only offers products to meet the needs of products that are not or not needed by the community (political economy of desire). These needs are created through the pieces of image that are considered the most representative of a product. In the context of beauty product advertisements, pseudo-needs are produced through the presence of beautiful hair images, tall lean bodies with white skin and beautiful faces displayed by models.

Of the many ads that exist in the media, beauty product advertising is the most aggressively toying with consumer desires, including advertising hair care products. Most of the ads are even very open using anxiety against the imperfections of women's body condition as advertising material. The involvement of beautiful women and beautiful hair as an advertising model led to an identity crisis. Women as the biggest consumer of beauty products always compare themselves with the perfect picture of the advertising stars. So what comes later is the phrases of dissatisfaction, for example, "I hate my hair!" Or "My hair makes things worse!"

Not only the influence of the presence of beautiful women as the advertising star of a product that makes other women as consumers always feel restless. The presence of men who seem to have the authority to assess the quality of women also contributes greatly to causing the anxiety to worsen. Here are the opinions of men about what they first thought about when meeting women, such as about in the June 2007 edition of Man Manual of Cosmopolitan magazine [8] 
The first thing I noticed when I met a woman was a crown, aka her hair. If you look at this topmost aspect, the women I meet will fall into two general categories. Firstly, they are with perfect hair blow and full of stamina throughout the day. Yes, those who seem to never be found out of the house with the appearance of a kucel. Always neat and flawless. There is some data coming in my head when meeting a woman like that: dare to appear, want to always be the center of attention and can be a bit difficult to be treated alias haig maintenance. Then, there is a category of women who make the crown as the priority of the umpteenth, so not as clean as the previous category. The thoughts that go right in the head after seeing them are: want to just rip it off, they include women who are more relaxed about appearance.

The next effect of this dissatisfaction with the condition of the body is the desire to 'be like', with the advertising model as its reference. Meanwhile, if the process of self-identification becomes uncontrolled, then what happens is the process of imitation blindly (mimetic erisis). In this case, the traditional institution of identity-forming, such as family, religion and occupation, has lost its role and function. The role of the institution has been taken over by the media that always provide solutions for women's confidence crisis through advertising impressions from various beauty products. The media became the most important socialization agent of the century. His ability to infiltrate the most private spaces in all circles, without exception, makes the media into comrades as well as opponents as society.

\section{CONCLUSION}

Hair as a symbol of women's identity on the one hand is physical and private, while on the other hand is public. Each person can form hair in various ways according to his personality. They can present different hairstyles between one woman and another to highlight her identity. In this case, the abundance of hair care and grooming products in markets is a form of industry democratization that provides an opportunity for women to express themselves. Advertising in mass media into a catalog, which always provides the latest lifestyle guidance. Women have the opportunity to choose the type, color and hair style they want without regard to the norms prevailing in the community.

However, along with the development of the manufacturing industry and the media industry, the individual ownership of women's hair is shifting. Hair has become public property. Its existence is continuously defined by the industry through various beauty products. Its needs are engineered in such a way by the advertisements displayed in the mass media. In this context, the freedom of women to determine their identity through the hair they possess is only false freedom. Consumption of women on beauty products actually led them to the process of subjectivication by industry. Meanwhile, as media consumers, their self-identity is systematically constructed through the lifestyle trends offered by the mass media. The existence of women as an individual is threatened.
How should women respond to these conditions? There is only one thing that is needed by women to truly gain freedom, that is consciousness. Distress will help us to translate the messages contained in the media texts [6] and direct us not to fall into the circle of industrial exploitation. The women's awareness of who he is and what he wants, not only helps them avoid the negative looks of capitalism, but also opens the opportunity to capitalize on capitalism.

With regard to hair, women should have the awareness to choose the look of hair that she wants. Identifying yourself with an admired celebrity is okay, provided that women have a good reason for their actions and not just follow-up. Beautiful face, well groomed body and beautiful hair is not a mistake. Precisely with the appearance, women can take social and economic benefits. Women's awareness of her potential will encourage them to take advantage of industry and the media, for example by becoming a beauty product ad star. On the one hand, the woman benefits financially and on the other hand she gains popularity which is a social advantage.

As a postmodern subject, women no longer have to worry about the changes they have to undergo (following trends). Because in this case, according to Hall [2], one's identity is a fragmented and diverse identity. An individual is not only composed of one identity, but consists of many identities that are sometimes contradictory. The process of self-identification was constantly changing. Therefore, identity is not a reflection of a fixed and natural state. Identity is the process of becoming, or for Giddens, identity is a project that is always in an interminable process.

\section{REFERENCES}

[1] A. Appadurai, Modernity at Large: Cultural Dimensions of Globalization. London: The University of Minnesota Press, $1996 .$.

[2] C. Barker, Cultural Studies: Teori dan Praktik (Edisi Revisi). Yogyakarta: Kreasi Wacana, 2008..

[3] S. Ewen, All Consuming Images: the Politics of Style ini Contemporary Culture (With New Introduction). USA: Basic Book, 1999.

[4] P. Falk, The Consuming Body. London: Sage Publications, 1994..

[5] L. Grossberg, Media Making: Mass Media in Popular Culture (Second Edition). London: Sage Publications, 2006.

[6] M.R. Real, Exploring Media Culture: a Guide. London: Sage Publications, 1996.

[7] A. Synnott, Tubuh Sosial: Simbolisme, Diri dan Masyarakat (edisi Bahasa Indonesia). Yogyakarta: Jalasutra, 2003.

[8] Majalah Cosmopolitan Edisi Juni 2007

[9] Majalah Cosmopolitian Edisi Oktober 2007

[10] http://www.kerastase.com

[11] http://www.koseindonesia.com

[12] http://www.lancome.com

[13] http://www.lionwings.com

[14] http://www.mandom.com

[15] http://www.ratukosmetik.com

[16] http://www.sinarharapan.com

[17] http://www.unilever.com

[18] http://www.youtube.com/iklan 